Abstracta Iranicacta Iranica

Revue bibliographique pour le domaine irano-aryen

Volume 27 | 2006

Comptes rendus des publications de 2004

\title{
Collection of Papers on Iranian Studies in China. Vol III, Peking University Press, 2003.
}

\section{Yidan Wang}

\section{(2) OpenEdition \\ 1 Journals}

Édition électronique

URL : http://journals.openedition.org/abstractairanica/5425

DOI : 10.4000/abstractairanica. 5425

ISSN : 1961-960X

\section{Éditeur :}

CNRS (UMR 7528 Mondes iraniens et indiens), Éditions de l'IFRI

\section{Édition imprimée}

Date de publication : 15 mai 2006

ISSN : 0240-8910

\section{Référence électronique}

Yidan Wang, "Collection of Papers on Iranian Studies in China. Vol III, Peking University Press, 2003. », Abstracta Iranica [En ligne], Volume 27 | 2006, document 4, mis en ligne le 02 janvier 2007, consulté le 25 septembre 2020. URL : http://journals.openedition.org/abstractairanica/5425 ; DOI : https:// doi.org/10.4000/abstractairanica.5425

Ce document a été généré automatiquement le 25 septembre 2020.

Tous droits réservés 
Collection of Papers on Iranian Studies in China. Vol III, Peking University Press, 2003.

Yidan Wang 
1 The third volume of this collection consists of 22 papers submitted to the "Third Conference of Iranian Studies in China" held by the Institute of Iranian Culture Studies at Peking University in November 2002. These papers reflect the latest achievements of Chinese scholars in the field of Iranian studies.

2 A common subject of many papers in this collection is the Sino-Iranian cultural relations and influences from the archaeological point of view. New archaeological findings and cultural relics, such as Persian coins, glassware, gold vessels and silverwares, tombs and tombstones along the Silk Road within China have provided new stimulations and perspectives for the Iranian studies in China. "The Persian Cultural Elements on the Images of the Stone Coffin of Yuhong" (by Zhang Qingjie) and "The Islamic Glass Unearthed in China" (by Qi Dongfang) represent the new results of such archaeological investigations in China.

3 Several papers focus on religion study. New attempts have been made to understand the religious texts and documents. "New Study on 'The First Voice' in the Chinese Hymnscroll" (by Ma Xiaohe) engaging in a textual research and criticism on a Chinese Manichaean hymn found in Dunhuang and "The 'Seven Times' on the Nestorian Tombstone” (by Duan Qing) dealing with Nestorianism, a religion coming into China through Iran, are two representative works in this field.

Sogdian study has recently become popular among the scholars of the historical interrelationship between China and Western Districts. "Sabao and Sabo: on the Problems of the Leader of Sogdian Colonies during the Northern Dynasties, Sui and Tang Period" (by Rong Xinjiang) provides a convincing argument in making a clear distinction between Sabao and Sabo in Chinese historical documents.

There are also papers dealing with the various intricacies of Iranian languages, history, literature, science and technology with depth and insight.

\section{INDEX}

Thèmes : 1.2. Recueils d'articles : revues, colloques, ouvrages collectifs

\section{AUTEURS}

YIDAN WANG

Université de Bei Jing 